\title{
Role of arbuscular mycorrhizal fungi in soil and water conservation: a potentially unexplored domain
}

\author{
Trisha Roy, Uday Mandal, Debashis Mandal* and Devideen Yadav
}

There is a general consensus that nature-based biological measures can be used as a valuable tool to improve land quality. Microbial technology, e.g. use of mycorrhizal fungi, has been considered a beneficial option in the rehabilitation of disturbed and degraded lands. Mycorrhizal fungi are extremely important to improve soil aggregation and in turn the porosity, erodibility and even soil fertility. This article provides an insight into how mycorrhizal fungi might play a role in reclamation and revegetation of degraded lands with special focus on soil and water conservation. External hyphae of arbuscular mycorrhizal fungi (AMF) can bind the small soil particles into micro aggregates by producing a glycoprotein (glomalin) which alone can account for 30-60\% of carbon in undisturbed soils. Glomalin is derived specifically from the hyphae of AMF and has not been reported in any other fungal species. Besides agriculture, the presence of AMF in the grassland and forest ecosystems is also of great significance as it helps in establishment of native plant species, soil improvement and carbon storage. The increasing interest of soil conservationists in this glycoprotein is also highlighted in this article.

Keywords: Arbuscular mycorrhizal fungi, carbon storage, degraded lands, glycoprotein, soil and water conservation.

SoIL degradation has serious consequences on biomass productivity and environmental quality. Soil being a nonrenewable resource and the basis for $97 \%$ of all food production, strategies to prevent its depletion are critical for sustainable development ${ }^{1,2}$. In the past, natural environments were full of mycorrhiza that were associated with roots of most plants naturally. However, over time, due to soil erosion, drought, soil compaction, depletion of organic matter and other degradation factors, these symbiotic fungi have become less prevalent in soils, and their ecosystem benefits have reduced significantly ${ }^{3,4}$. Accelerated soil erosion is also among the most pressing environmental problems, resulting in degradation of ecosystem function, decreased productivity and agricultural sustainability ${ }^{5}$. The primary importance of mycorrhizal association in restoration and revegetation of degraded lands has been well recognized, and its reintroduction is essential to reverse degradation ${ }^{6}$.

The association between plant roots and mycorrhizal fungi is almost 450 million years old. This symbiotic association is one of the most important components of the sustainable soil plant system ${ }^{7}$ and is present in majority

\footnotetext{
Authors are in the ICAR-Indian Institute of Soil and Water Conservation, Dehradun 248 195, India.

*For correspondence. (e-mail: dmandalcswcrti@gmail.com)
}

of plant species, barring a few ${ }^{8}$. The fungal hyphae act as an extension of the plant root system and help in better acquisition of nutrients through exploring more soil volume. The plant gets benefitted in terms of higher nutrient availability, whereas the fungus derives food from the plant and coexists along with the plant roots. The nutrient-supplying capacity of vesicular-arbuscular mycorrhiza (VAM) can reach up to almost $80 \%$ for phosphorus $(\mathrm{P}), 25 \%$ for nitrogen $(\mathrm{N})$ and zinc $(\mathrm{Zn}), 10 \%$ for potassium $(\mathrm{K})$ and $60 \%$ for copper $(\mathrm{Cu})^{9}$. This helps in improving plant growth and productivity, as well as alleviating drought stress and reducing the incidence of pathogen infections ${ }^{10}$. Besides the direct impact, VAM also modifies the rhizosphere soil. The hyphae act as extended plant roots forming a mesh-like structure. This is capable of binding the soil particles and enhances aggregate formation. This active role of VAM in soil aggregation makes it a potent soil conservation agent with multitude of benefits being derived from it.

\section{Arbuscular mycorrhizal fungi and soil aggregation}

Soil erosion involves breakdown of aggregates and separation of soil particles (disruption of soil structure), followed by relocation and deposition of sediments. Each 
erosion process has a strong influence on the state and dynamics of soil organic carbon $(\mathrm{SOC})^{11}$, as it is closely associated with soil structure. The soil structure is also central to various soil functions like nutrients, moisture and gaseous fluxes ${ }^{12}$. Thus for soil conservation, healthy soil structure is a prime prerequisite. Soil structure is simply defined as the arrangement of soil separates (i.e. sand, silt and clay) into micro $(<0.25 \mathrm{~mm}$ diameter) and macro $(>0.25 \mathrm{~mm}$ diameter $)$ aggregates. The micro aggregates are bound further with the help of different primary mechanisms, of which the arbuscular mycorrhizal fungi (AMF) hyphae play a crucial role. Micro aggregates are glued to each other by transient binding agents such as polysaccharides and polyuronides to form macro aggregates. The contribution of the fungal hyphae in soil formation, however, varies with the position of the soil, i.e. rhizosphere or non-rhizosphere. The rhizosphere soil is more effectively bound by AMF hyphae, but its influence reduces greatly in the nonrhizosphere soil. This is because AMF is an obligate symbiont and cannot survive in the absence of host plant roots. The contribution of AMF in the soil aggregation process can be described by three steps as follows ${ }^{13}$.

- The hyphae may act as a structural support to hold the sand, silt and clay together to form the aggregate.

- The hyphae along with plant roots provide a conducive environment for the formation of micro aggregates.

- The hyphae act as a mesh and help in entangling the micro aggregates together to form macro aggregates.

These three steps are not exclusive, but occur simultaneously within the soil. The hyphae play a major role in bringing about soil aggregation and improving soil stability. Thus using AMF for soil conservation provides double benefit through the production of extracellular polymeric substances as well as hyphae for soil aggregation ${ }^{14}$.

\section{Factors affecting the growth of AMF vis-à-vis conservation}

\section{Nutrient concentration in soil}

Nutrients in the soil have a strong influence on the growth, sporulation and efficiency of AMF. One of the widely studied nutrients in relation to AMF is $\mathrm{P}$. AMF play an important role in increasing $\mathrm{P}$ availability to plants by exploring larger soil volumes and mobilizing $\mathrm{P}$ through extended hyphal network. Contrasting reports related to the effect of $\mathrm{P}$ fertilization on AMF colonization exist in the literature. Root colonization by AMF is reported to increase under continuous $\mathrm{P}$ fertilization ${ }^{15}$, whereas reduction in spore density due to $\mathrm{P}$ fertilization in comparison to $\mathrm{P}$ non-fertilized plots has also been ob- served $^{16}$. Generally $\mathrm{P}$ deficiency activates AMF sporulation leading to higher spore densities under non-fertilized conditions. However, irrespective of the soil P status, presence of AMF enhances P supply to the host plants.

With respect to N, no singular trend exists in the literature. Reduction in the colonization of roots due to longterm application is reported in some studies ${ }^{17}$, while others indicate an increase in AM hyphae and glomalinrelated soil protein (GRSP) due to $\mathrm{N}$ fertilization ${ }^{18}$.

\section{Soil temperature}

Soil temperature plays an important role in determining the colonization of plant roots by mycorrhiza. Generally, temperature lower than or equivalent to $5^{\circ} \mathrm{C}$ effects colonization and the plants are not able to be inoculated ${ }^{19}$. With increase in soil temperature between $10^{\circ} \mathrm{C}$ and $30^{\circ} \mathrm{C}$, increasing colonization of the roots occurs. Overall, a temperature between $6^{\circ} \mathrm{C}$ and $18^{\circ} \mathrm{C}$ reduces the translocation of $\mathrm{C}$ from host plants to $\mathrm{AMF}$ and reduces their growth $^{20}$. However, $\mathrm{P}$ translocation to plants via $\mathrm{AMF}$ hyphae is not affected in the temperature range $10^{\circ} \mathrm{C}$ to $25^{\circ} \mathrm{C}$ (ref. 21). Overall, care should be taken to avoid applying inoculum if soil temperature is $<7^{\circ} \mathrm{C}$ (ref. 22).

\section{Soil moisture and aeration}

The importance of soil moisture in AMF inoculation depends on both the plant species and AMF species, and cannot be generalized ${ }^{23}$. Commonly inoculation with AMF can provide tolerance against extreme drought conditions as well as waterlogging situations ${ }^{24,25}$. Increased soil moisture content up to field capacity or higher enhances AMF colonization by plant roots ${ }^{23,26}$. AMF help in alleviating drought stress through their indirect influence on water-stable aggregates ${ }^{27}$. AMF are aerobic in nature, and highly waterlogged soil conditions adversely influence their growth and colonization ${ }^{28,29}$. Highly waterlogged soils show poor vertical distribution of AMF as well as surface concentration of fungi population, indicating poor colonization ${ }^{30}$.

\section{Soil $p H$}

Soil $\mathrm{pH}$ plays an important role in determining the inoculation of AMF in plants. The different AMF species respond differently towards soil $\mathrm{pH}$. Though there is no optimum $\mathrm{pH}$ range favourable for $\mathrm{AMF}$ colonization, neutral to slightly alkaline $\mathrm{pH}$ is preferred by $\mathrm{AMF}^{22}$. Infestation with Glomus fasiculatum occurs extensively between $\mathrm{pH} 5.3$ and 7.5, whereas Glomus sp. (WUM16) is able to colonize clover roots only at higher $\mathrm{pH}^{31}$. A pH drop beyond 5.5 reduced infestation in oats ${ }^{32}$, whereas chia plants showed highest inoculation when grown under 
P-limited alkaline conditions ( $\mathrm{pH} 8.2)^{33}$. On the contrary, AMF associated with forest tree species like pine, oak, etc. which are acidophilic in nature, cannot survive in neutral to alkaline conditions ${ }^{34}$.

\section{Crop rotation and tillage}

Different crops have varying capacities to colonize with AMF, and crop rotation strongly influences AMF population in the soil. A rotation of wheat-chickpea witnessed $60 \%$ higher AMF colonization in wheat when grown after chickpea compared to wheat-canola crop rotation ${ }^{35}$. Since AMF are obligate symbionts, presence of a host plant is essential for their survival. Rotation of a host plant (like cowpea) with a non-host plant (like mustard) resulted in $13 \%$ decline in AMF population, while keeping the land fallow reduced AMF up to 40\% (ref. 36). Therefore, to maintain a healthy, inherent AMF population in the soil, suitable host crop species are essential ${ }^{37}$.

Intensive tillage operations disrupt the growth of roots as well as fungal hyphae, and AMF population reduces under heavy tillage practices. Thus, conservation tillage, minimum and reduced tillage which causes minimum disturbance of the soil, enhances growth and development of AMF propagules.

\section{Soil organic matter}

Higher organic matter positively influences AMF population. Long-term fertilization experiments, including addition of straw and farmyard manure (FYM) encourage the growth and biodiversity of $\mathrm{AMF}^{38}$.

\section{Impact of AMF on soil and water conservation}

AMF actively participate in the process of soil and water conservation through improvement in soil aggregation, increase in the water-stable aggregates and protecting the SOC. With the discovery of glomalin, a protein of AMF origin $^{39,40}$, the role of AMF in soil conservation is being refurbished.

\section{AMF hyphae, soil aggregation and conservation}

The association of AMF with host plants has a positive impact on root architecture and influences the moisture regime in the rhizosphere. AMF offer more efficient water utilization, thus leading to stronger wetting-drying cycles and stronger aggregates ${ }^{41}$. AMF association modifies host $\mathrm{C}$ metabolism, bringing about qualitative and quantitative changes in root exudates, and subsequently influencing aggregate formation ${ }^{42}$. There has been effective reduction in soil loss due to surface-water flow when AMF inoculation was used in a greenhouse experiment to grow Achillea millefolium ${ }^{43}$. The AMF inoculation was instrumental in river-bank slope stabilization and restoration of ecological functions when inoculated along with native plant species as a vegetative measure of soil conservation $^{44}$. Increased mean weight diameter and geometric mean diameter of soil due to inoculation with $\mathrm{AMF}^{45,46}$ confirm the role of fungal hyphae in improving soil structure and their contribution towards soil conservation.

\section{Role of glomalin in soil conservation}

The discovery of glomalin has led to many new avenues of contribution of AMF in soil conservation ${ }^{39,40}$. The increasing interest of soil conservationists in this glycoprotein is mainly attributed to two factors ${ }^{12}$ :

(a) The technique of $\mathrm{C}$ dating has proved the age of existing soil glomalin to be over several years to decades, indicating that it remains intact in the soil even when the AMF growth is arrested/restricted.

(b) The contribution of glomalin $\mathrm{C}$ and $\mathrm{N}$ to the total soil $\mathrm{C}$ and $\mathrm{N}$ is almost $4-5 \%$ in the older soils, which is higher than the contribution of microbial biomass $\mathrm{C}$.

In some undisturbed soils, glomalin can exclusively account for $30-60 \%$ of soil C (ref. 47 ).

The high stability of glomalin at temporal scale and its contribution to the total $\mathrm{C}$ pool makes it a prominent player in the mechanisms of $\mathrm{C}$ storage and stabilization, $\mathrm{C}$ sequestration and consequently mitigation of the impact of climate change. Generally, all $\mathrm{C}$ products derived from AMF hyphae are placed under the umbrella of GRSP to distinctly define their source and origin.

Under the climate change scenario, elevated $\mathrm{CO}_{2}$ concentration might trigger the production of more glomalin, increase aggregate stabilization and protection of aggregate-associated C (ref. 48). On the other hand, increased temperature and moisture stress can negate such impacts. In general, GRSP is found to be effective in the protection of $\mathrm{C}$ in deeper soil layers, and the ratio of glomalin to soil organic $C$ was $1.34-1.5$ times higher in $80-100 \mathrm{~cm}$ soil layers in comparison to the surface layer of $0-20 \mathrm{~cm}$ (ref. 49). Also, GRSP is more closely associated with C protection in grassland and forest soils than arable land ${ }^{50}$. It is estimated that erosion control would reduce $\mathrm{C}$ emission to the tune of 19-27 $\mathrm{Tg} \mathrm{C} \mathrm{yr}^{-1}$ (ref. 51), and GRSP can play an important role in this regard.

\section{Conclusion}

The omnipresent nature of AMF in the ecosystem makes them a significant contributor towards crop production and maintenance of agricultural systems in a sustainable 
manner. The use of AMF in the cropping system holds great promise in improving crop growth, alleviating $\mathrm{P}$ and moisture stress, improving soil aggregation, and soil structure. The impact of AMF in stabilizing the aggregates proves encouraging for soil conservation. However, several management practices have a negative impact on the AMF, which should be minimized to maintain the native or externally inoculated AMF population.

1. Mandal, D. and Sharda, V. N., Assessment of permissible soil loss in India employing a quantitative bio-physical model. Curr. Sci., 2011, 100(3), 383-390.

2. Mandal, D. and Tripathi, K. P., Soil erosion limits for Lakshadweep Archipelago. Curr. Sci., 2009, 96(2), 276-280.

3. Mozafar, A., Anken, T., Ruh, R. and Frossard, E., Tillage intensity, mycorrhizal and nonmycorrhizal fungi, and nutrient concentrations in maize, wheat, and canola. Agron. J., 2000, 92, 1117-1124.

4. Oehl, F., Sieverding, E., Ineichen, K., Mäder, P., Boller, T. and Wiemken, A., Impact of land use intensity on the species diversity of arbuscular mycorrhizal fungi in agroecosystems of central Europe. Appl. Environ. Microbiol., 2003, 69, 2816-2824.

5. Lenka, N. K., Mandal, D. and Sudhishri, S., Permissible soil loss limits for different physiographic regions of West Bengal. Curr. Sci., 2014, 107(4), 665-670.

6. Quoreshi, A. M., The use of mycorrhizal biotechnology in restoration of disturbed ecosystem. In Mycorrhizae: Sustainable Agriculture and Forestry (eds Siddiqui, Z. A. et al.), Springer Science + Business Media B.V., 2008, pp. 303-320.

7. Hooker, J. E., Black, K. E., Perry, R. L. and Atkinson, D., Arbuscular mycorrhizal fungi induced alteration to root longevity of poplar. Plant Soil, 1995, 172(2), 327-329.

8. Yakop, F., Taha, H. and Shivanand, P., Isolation of fungi from various habitats and their possible bioremediation. Curr. Sci., 2019, 116(5), 733-740.

9. Marschner, H. and Dell, B., Nutrient uptake in mycorrhizal symbiosis. Plant Soil, 1994, 159(1), 89-102.

10. Piotrowski, J. S., Annis, S. L. and Longcore, J. E., Physiology of Batrachochytrium dendrobatidis, a chytrid pathogen of amphibians. Mycologia, 2004, 96(1), 9-15.

11. Mandal, D. et al., ${ }^{137} \mathrm{Cs}-\mathrm{a}$ potential environmental marker for assessing erosion-induced soil organic carbon loss in India. Curr. Sci., 2019, 117(5), 865-871.

12. Rillig, M. C., Sara, F. W. and Valerie, T. E., The role of arbuscular mycorrhizal fungi and glomalin in soil aggregation: comparing effects of five plant species. Plant Soil, 2002, 238, 325-333.

13. Miller, R. M. and Jastrow, J. D., The role of mycorrhizal fungi in soil conservation. Mycorrhizae Sustain. Agric., 1992, 54, 2944.

14. Costa, O. Y. A., Raaijmakers, J. M. and Kuramae, E. E., Microbial extracellular polymeric substances. Ecological function and impact on soil aggregates. Front. Microbiol., 2018, 9, 1636; doi:10.3389/fmicb.2018.01636.

15. Graham, J. H. and Abott, L. K., Wheat responses to aggressive and non-aggressive arbuscular mycorrhizal fungi. Plant Soil, 2000, 220, 207-218.

16. Xie, H., Li, J., Zhang, B., Wang, L., Wang, J., He, H. and Zhang, $\mathrm{X}$., Long-term manure amendments reduced soil aggregate stability via redistribution of the glomalin-related soil protein in macroaggregates. Sci. Rep., 2015, 5, 14687.

17. Mader, P., Fliessbach, A., Dubois, D., Gunst, L., Fried, P. and Niggli, U., Soil fertility and biodiversity in organic farming. Science, 2002, 296, 1694-1697; doi:10.1126/science.1071148.

18. Wilson, G. W., Rice, C. W., Rillig, M. C., Springer, A. and Hartnett, D. C., Soil aggregation and carbon sequestration are tightly correlated with the abundance of arbuscular mycorrhizal fungi: results from long-term field experiments. Ecol. Lett., 2009, 12(5), 452-461.

19. Domisch, T., Finér, L., Lehto, T. and Smolander, A., Effect of soil temperature on nutrient allocation and mycorrhizas in Scots pine seedlings. Plant Soil, 2002, 239(2), 173-185.

20. Gavito, M. E., Olsson, P. A., Rouhier, H., Medina-Peñafiel, A., Jakobsen, I., Bago, A. and Azcón-Aguilar, C., Temperature constraints on the growth and functioning of root organ cultures with arbuscular mycorrhizal fungi. New Phytol., 2005, 168(1), 179188.

21. Wang, B., Funakoshi, D. M., Dalpe, Y. and Hamel, C., Phosphorus-32 absorption and translocation to host plants by arbuscular mycorrhizal fungi at low root-zone temperature. Mycorrhiza, 2002, 12, 93-96.

22. https://www.lebanonturf.com/education-center/biological-planttreatments/mycorrhizalfungi-and-ph-of-soil-or-water (accessed on 4 January 2020).

23. Shukla, A., Kumar, A., Jha, A., Salunkhe, O. and Vyas, D., Soil moisture levels affect mycorrhization during early stages of development of agroforestry plants. Biol. Fert. Soils, 2013, 49(5), 545554.

24. Auge, R. M., Water relations, drought and vesicular-arbuscular mycorrhizal symbiosis. Mycorrhiza, 2001, 11, 3-42.

25. Mendoza, R., Escudero, V. and Garcia, I., Plant growth, nutrient acquisition and mycorrhizal symbioses of a waterlogging tolerant legume (Lotus glaber Mill.) in a saline-sodic soil. Plant Soil, 2005, 275, 305-315.

26. Karasawa, T., Arihara, J. and Kasahara, Y., Effects of previous crops on arbuscular mycorrhizal formation and growth of maize under various soil moisture conditions. Soil Sci. Plant Nutr., 2000, 46, 53-60

27. Tahat, M. M. and Sijam, K., Mycorrhizal fungi and abiotic environmental conditions relationship. Res. J. Environ. Sci., 2012, 6(4), 125-188.

28. Melin, E., Physiology of mycorrhizal relations in plants. Annu. Rev. Plant Physiol., 1953, 4, 325-346.

29. Melin, E., Die Bedeutung der Mycorrhiza fur die Versorgung der Pflanze mit Mineralstoffen. In Handbuch der Pjlanzenphysiologie (ed. Ruhland, W.), Springer, Berlin, Germany, 1958, p. 1210.

30. Paavilainen, E., On the effect of drainage on root systems of Scots pine on peat soils. Commun. Inst. For. Fenn., 1966, 66(1), 1-100.

31. Abbott, L. K. and Robson, A. D., The effect of soil $\mathrm{pH}$ on the formation of VA mycorrhizas by two species of Glomus. Soil Res., 1985, 23(2), 253-261.

32. Wang, G. M., Stribley, D. P., Tinker, P. B. and Walker, C., Effects of $\mathrm{pH}$ on arbuscular mycorrhiza I. Field observations on the longterm liming experiments at Rothamsted and Woburn. New Phytol., 1993, 124(3), 465-472.

33. Ouzounidou, G., Skiada, V., Papadopoulou, K. K., Stamatis, N., Kavvadias, V., Eleftheriadis, E. and Gaitis, F., Effects of soil pH and arbuscular mycorrhiza (AM) inoculation on growth and chemical composition of chia (Salvia hispanica L.) leaves. Braz. J. Bot., 2015, 38(3), 487-495.

34. Richards, B. N., Soil pH and mycorrhiza development in Pinus. Nature, 1961, 190(4770), 105.

35. Bakhshandeh, S., Corneo, P. E., Mariotte, P., Kertesz, M. A. and Dijkstra, F. A., Effect of crop rotation on mycorrhizal colonization and wheat yield under different fertilizer treatments. Agric. Ecosyst. Environ., 2017, 247, 130-136.

36. Harinikumar, K. M. and Bagyaraj, D. J., Effect of crop rotation on native vesicular arbuscular mycorrhizal propagules in soil. Plant Soil, 1988, 110(1), 77-80.

37. Haider, K. R., The effect of cropping rotation and management on arbuscular mycorrhizal fungi in a sustainable dairy cropping system, 2014; https://etda.libraries.psu.edu/catalog/22664 (accessed on 5 January 2020). 
38. Wu, F., Dong, M., Liu, Y., Ma, X., An, L., Young, J. P. W. and Feng, H., Effects of long-term fertilization on AM fungal community structure and Glomalin-related soil protein in the Loess Plateau of China. Plant Soil, 2011, 342(1-2), 233-247.

39. Wright, S. F., Franke-Snyder, M., Morton, J. B. and Upadhyaya, A., Time-course study and partial characterization of a protein on hyphae of arbuscular mycorrhizal fungi during active colonization of roots. Plant Soil, 1996, 181(2), 193-203.

40. Wright, S. F., Rillig, M. C. and Nichols, K. A., Glomalin: a soil protein important in carbon sequestration. In Proceedings of the American Chemical Society Annual Meeting Symposium, 2000, pp. $721-725$.

41. Six, J., Bossuyt, H., Degryze, S. and Denef, K., A history of research on the link between (micro) aggregates, soil biota, and soil organic matter dynamics. Soil Till. Res., 2004, 79(1), 7-31.

42. Morel, J. L., Habib, L., Plantureux, S. and Guckert, A., Influence of maize root mucilage on soil aggregate stability. Plant Soil, 1991, 136(1), 111-119.

43. Mardhiah, U., Caruso, T., Gurnell, A. and Rillig, M. C., Arbuscular mycorrhizal fungal hyphae reduce soil erosion by surface water flow in a greenhouse experiment. Appl. Soil Ecol., 2016, 99, 137140; https://doi.org/10.1016/j.apsoil.2015.11.027

44. Kimura, A. C. and Scotti, M. R., Soil aggregation and arbuscular mycorrhizal fungi as indicators of slope rehabilitation in the São Francisco River basin (Brazil). Soil Water Res., 2016, 11(2), 114-123.

45. Celik, I., Ortas, I. and Kilic, S., Effects of compost, mycorrhiza, manure and fertilizer on some physical properties of a chromoxerert soil. Soil Till. Res., 2004, 78, 59-67.
46. Bearden, B. N. and Petersen, L., Influence of arbuscular mycorrhizal fungi on soil structure and aggregate stability of a Vertisol. Plant Soil, 2000, 218, 173-183.

47. Treseder, K. K. and Allen, M. F., Mycorrhizal fungi have a potential role in soil carbon storage under elevated $\mathrm{CO}_{2}$ and nitrogen deposition. New Phytol., 2000, 147, 189-200.

48. Wright, S. F. and Anderson, R. L., Aggregate stability and glomalin in alternative crop rotations for the central Great Plains. Biol. Fert. Soil, 2000, 31(3-4), 249-253.

49. Wang, W., Zhong, Z., Wang, Q., Wang, H., Fu, Y. and He, X., Glomalin contributed more to carbon, nutrients in deeper soils, and differently associated with climates and soil properties in vertical profiles. Sci. Rep., 2017, 7(1), 13003.

50. Xu, M., Li, X., Cai, X., Li, X., Christie, P. and Zhang, J., Land use alters arbuscular mycorrhizal fungal communities and their potential role in carbon sequestration on the Tibetan Plateau. Sci. Rep., 2017, 7(1), 3067.

51. Mandal, D., Giri, N. and Srivastava, P., The magnitude of erosioninduced carbon (C) flux and C-sequestration potential of eroded lands in India. Eur. J. Soil Sci., 2020, 71(2), 151-168.

Received 18 January 2020; revised accepted 2 February 2021

doi: $10.18520 / \mathrm{cs} / \mathrm{v} 120 / \mathrm{i} 10 / 1573-1577$ 